\title{
Infrared thermography of the body surface in the Eurasian otter Lutra lutra and the giant otter Pteronura brasiliensis
}

\author{
Rachel A. Kuhn ${ }^{1,2}$, Wilfried Meyer ${ }^{3, *}$ \\ ${ }^{1}$ Aktion Fischotterschutz e.V., Otter-Zentrum, 29386 Hankensbüttel, Germany \\ ${ }^{2}$ Institute of Zoology, University of Hamburg, Martin-Luther-King-Platz 3, 20146 Hamburg, Germany \\ ${ }^{3}$ Institute for Anatomy, University of Veterinary Medicine Hannover Foundation, Bischofsholer Damm 15, \\ 30173 Hannover, Germany
}

\begin{abstract}
The body surface temperatures of the Eurasian otter Lutra lutra and the tropical giant otter Pteronura brasiliensis were studied based on detailed infrared thermography. The Eurasian otter mainly used its feet to dissipate excess heat, whereas the giant otter lost more heat from the whole body and tail. In both species, the temperature at the surface of the feet tended to decrease to a temperature similar to that of the water when the animal was submerged. The same was observed for the tail of the giant otter, and of the Eurasian otter during winter. In the Eurasian otter, temperatures of the air layer trapped within the fur were $>10^{\circ} \mathrm{C}$ above the temperature of the ambient air or water. A specific heating of sensory organs on the head could be observed.
\end{abstract}

KEY WORDS: Otter · Lutra lutra · Pteronura brasiliensis · Infrared thermography · Thermoregulation · Thermal windows

\section{INTRODUCTION}

All objects with a surface temperature above absolute zero $\left(0 \mathrm{~K}=-273.15^{\circ} \mathrm{C}\right)$ emit electromagnetic radiation (Speakman \& Ward 1998). Using physical principles, it is possible to calculate the surface temperature of objects from the wavelength and intensity of electromagnetic radiation emitted in the infrared region of the spectrum. This feature, which allows measurement of the surface temperature of an object without physical contact, is called infrared thermography (IRT).

Infrared technology is currently used in astronomy, construction, industrial and research settings, and includes also a great number of biological applications. Thermal imaging has become of increasing interest as a research tool in investigating animal thermoregulation. IRT contributes to our understanding of how animals are adapted to their environment, because it demonstrates the functioning of mechanisms of heat dissipation and heat conservation (e.g. Phillips \& Sanborn 1994, McCafferty et al. 1998). Considering mammals that live entirely or partly in the aquatic environment, work on thermoregulation using IRT has been done with seals (e.g. Øritsland 1968, Mauck et al. 2003), cetaceans (e.g. Cuyler et al. 1992, Pabst et al. 2002), polar bears (Øritsland et al. 1974) and beavers (Zahner \& Müller 2003).

As for other aquatic and semi-aquatic animals, it is a great challenge for otters (Lutrinae) to maintain their body temperature in water, because the conductivity of the latter medium is $>25$-fold that of air. Nevertheless, these mammals achieve this requirement through special adaptive features, like a highly insulating hair coat and an elevated metabolism. However, a thick hair coat reduces the surface available for heat exchange, and thus could lead to overheating. A considerable amount of work has been done on otter metabolism, thermoregulation and the insulative properties of their fur. The species studied most often are the sea otter 
Enhydra lutris, the North American river otter Lontra canadensis and the Eurasian otter Lutra lutra (e.g. Kenyon 1969, Iversen \& Krog 1973, Morrison et al. 1974, Tarasoff 1974, Costa \& Kooyman 1984, Williams 1989, Kruuk \& Balharry 1990, Williams et al. 1992, Kruuk et al. 1994, 1997, Pfeiffer \& Culik 1998, Fish et al. 2002, Weisel et al. 2005).

None of the above-mentioned studies have assessed body surface temperature using IRT. Thus, a study of body surface temperature using thermal imaging was conducted for the Eurasian otter Lutra lutra, in order to document which parts of the body are important thermoregulatory surfaces and to demonstrate which mechanisms are involved in heat conservation or dissipation. Moreover, the influence of activity and weather conditions on the surface temperature of different body parts was analysed. IRT also allowed us to measure the difference between the temperature at the surface of the body (surface of the fur) and the temperature within the fur, close to the epidermis, and thus to illustrate in a new way the insulative properties of the hair coat of otters. In order to compare the results with data obtained for an otter species living in different environmental conditions, measurements were carried out on an otter species exemplary of life in tropical regions: the giant otter Pteronura brasiliensis.

\section{MATERIALS AND METHODS}

Infrared thermographic (IRT) study of the Eurasian otter Lutra lutra. A study of the body surface temperature of the Eurasian otter was conducted at the Otter Centre (Otter Zentrum) in Hankensbüttel, Germany, from May 2006 until January 2007. Thermal images of 7 Eurasian otters of both sexes were recorded using a FLIR ThermaCam B20. The measurements were made in May, June and December 2006 and in January 2007.

We focussed on a 3 yr old female (Naima), because this otter was very tame and kept alone in an enclosure separated from the exhibit area. Thermographic pictures were made on 26 occasions, which lasted 1 or 2 , or on exception $3 \mathrm{~h}$. It was possible to take pictures of the animal while grooming, sleeping outside and while in the sleeping box. On 5 occasions in May, Naima spent 30 to $40 \mathrm{~min}$ in an indoor part of the enclosure, usually not accessible for otters (actually the service room), which was the only way to get her active on land for such a long time. Additional measurements were made with 3 males kept together in an enclosure in the exhibit area (Tomasz, Kuno, Olli), 2 males kept together in another enclosure in the exhibit area (Robert, Lukas), and 1 male living alone in an enclosure (Teufel).
The distance between the otters and the camera ranged from 0.30 to $3 \mathrm{~m}$. We recorded the activity of the animals during the measurements, and also whether the otter was wet or dry. Air ( $\left.T_{\text {air }}\right)$ and water temperature $\left(T_{\text {water }}\right)$ were always recorded. The pictures were taken after sunset, on cloudy days, in shadowy places, or indoors, in order to avoid radiative heat gain. The pictures were additionally taken on days with little or no ambient wind, in order to avoid important convective heat loss.

IRT study of the giant otter Pteronura brasiliensis. The study of giant otters was conducted at the Hagenbeck Zoo (Hamburg, Germany) in September 2006. Thermal pictures of 2 adults (male and female) were taken during 3 sessions. During the first 2 sessions, which lasted $2 \mathrm{~h}$ and $30 \mathrm{~min}$, respectively, the otters were in an indoor heated enclosure with a pool. During the last session, they spent $1 \mathrm{~h}$ in a small part of the enclosure, with no access to the water. The distance between the thermocamera and otter ranged from 2 to $4 \mathrm{~m}$, except during the last session, where it was about $1 \mathrm{~m}$.

Thermal imaging and analysis of the thermograms. An emissivity of 0.95 was chosen, which is within the range of emissivity values for biological material (Porter \& Gates 1969, Speakman \& Ward 1998). For all pictures, a rainbow colour scheme was used. Since electromagnetic radiation travels in straight lines, errors due to angle distortion can occur. However, the effect of viewing angle is negligible for objects with a rough surface, such as animals, until the angle is $<10^{\circ}$ (Clark 1976, Speakman \& Ward 1998). Thus, when the angle between a surface and the line of sight of the thermocamera was $<10^{\circ}$, this surface was excluded from the analysis. The thermal images were analysed using the ThermaCAM QuickView software (FLIR). Mean temperature and standard deviation of a given area of the otter body were calculated using the temperature measured at 5 randomly chosen points situated within this area.

\section{RESULTS}

\section{Lutra lutra}

The otters studied were left in their usual enclosure and were unrestrained during the measurements, with a few exceptions (see 'Materials and methods'). Thus, they could go into their sleeping box or into the water whenever they wanted to, and they moved between water and land very often. Thermograms were made at ambient air temperatures ( $T_{\text {air }}$ ) ranging from 2.8 to $29.4^{\circ} \mathrm{C}$ and water temperatures $\left(T_{\text {water }}\right)$ ranging from 4.5 to $21.4^{\circ} \mathrm{C}$. All otters studied showed a similar thermoregulatory pattern. 


\section{Feet and legs}

The feet appeared to be the most important thermoregulatory surface for the Eurasian otter and temperatures between 4 and $39^{\circ} \mathrm{C}$ were measured at their surface. The feet of all otters studied were warmer than the rest of the body surface and warmer than $T_{\text {air }}$ each time they left the sleeping box or after a period of activity on land (Fig. 1A). Temperatures at the surface of the feet $\left(T_{\text {feet }}\right)$ up to $20^{\circ} \mathrm{C}$ above the temperature at the surface of the trunk ( $\left.T_{\text {trunk }}\right)$ were recorded, whereby the interdigital webbings were the warmest area. $T_{\text {feet }}$ decreased while the otter was in the water,
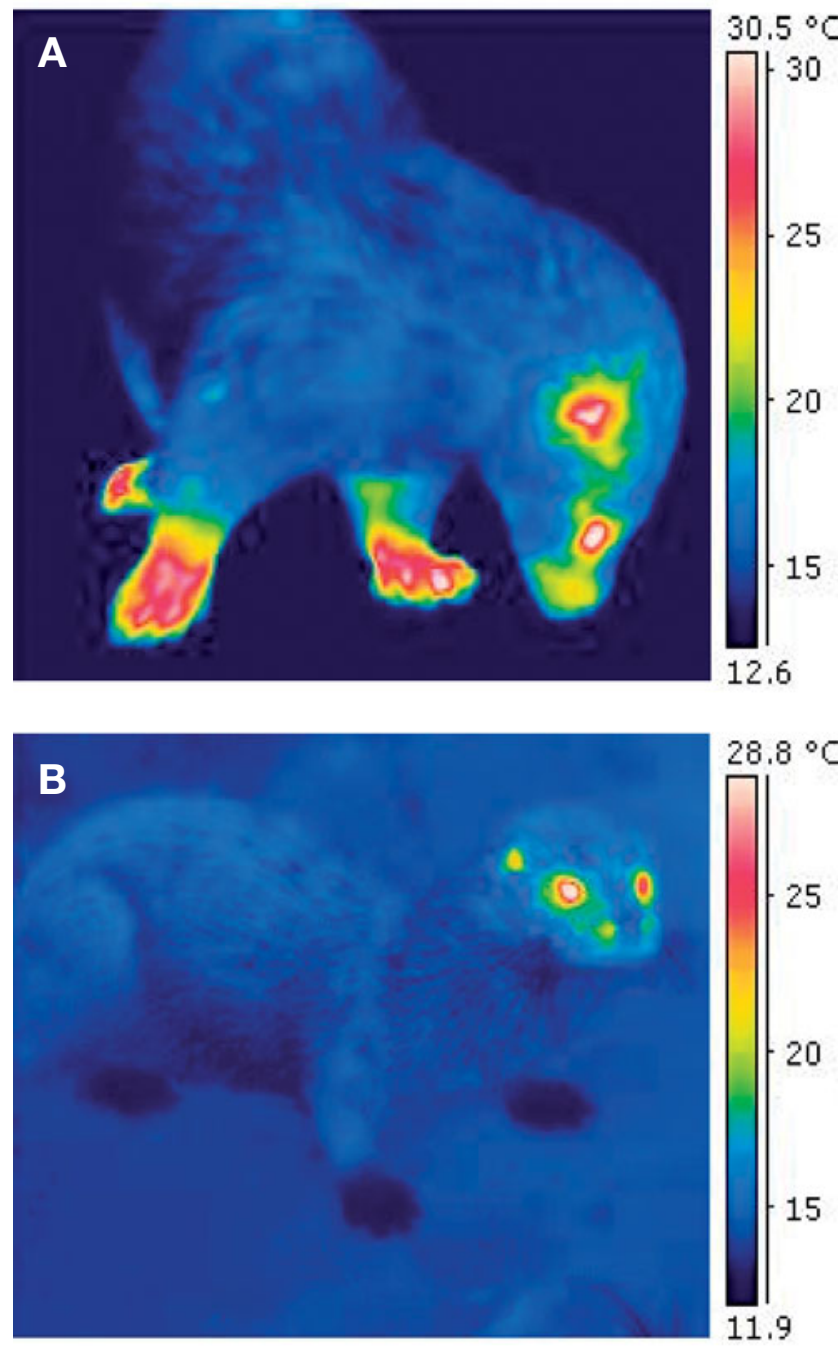

Fig. 1. Lutra lutra. (A) Thermogram of Naima $\left(T_{\text {air }}=12 \cdot 5^{\circ} \mathrm{C}\right)$. The feet were twice as warm as the rest of the body (except head); $T_{\text {trunk }}=14.5 \pm 1.1^{\circ} \mathrm{C}, T_{\text {feet }}=28.7 \pm 1.5^{\circ} \mathrm{C}(\mathrm{n}=5$ randomly chosen measuring points). (B) Thermogram of Tomasz taken just after a swimming bout $\left(T_{\text {air }}=15 \cdot 3^{\circ} \mathrm{C}, T_{\text {water }}=12 \cdot 2^{\circ} \mathrm{C}\right)$. Both trunk and feet were beneath $T_{\text {air. }}$. The feet were about $2^{\circ} \mathrm{C}$ colder than the rest of the body and had a surface temperature similar to $T_{\text {wateri }} T_{\text {trunk }}=14.4 \pm 0.3^{\circ} \mathrm{C}, T_{\text {feet }}=12.5 \pm 0.1^{\circ} \mathrm{C}$ and the feet then appeared colder than the rest of the body on the thermograms (Fig. 1B). When an otter had just left the water, the surface of the feet was usually at the same temperature as the water $\left(T_{\text {water }}\right)$ or slightly above. Afterwards, an increase of $T_{\text {feet }}$ could depend on $T_{\text {air }}, T_{\text {water }}$ and the intensity of activity (see Fig. 2). At $T_{\text {air }}>25^{\circ} \mathrm{C}$, the feet of a wet otter became warmer than $T_{\text {trunk }}$ and than $T_{\text {air }}$ after a few minutes of activity on land, independently of the time spent in the water. At lower temperatures, the increase of $T_{\text {feet }}$ after a swimming bout was slower, except when the otter was particularly active and excited. For example, during a winter session $\left(T_{\text {air }}=6.4^{\circ} \mathrm{C}, T_{\text {water }}=5.0^{\circ} \mathrm{C}\right), 1$ male (Teufel) entered the water with $T_{\text {trunk }}=9$ to $10^{\circ} \mathrm{C}$ and $T_{\text {feet }}=19$ to $20^{\circ} \mathrm{C}$. After $2 \mathrm{~min}$ in the water, $T_{\text {trunk }}$ was similar to $T_{\text {water }}$ and the feet were still at 17 to $18^{\circ} \mathrm{C}$. After $4 \mathrm{~min}$ of intense activity on land, $T_{\text {trunk }}$ was around $T_{\text {air }}\left(6\right.$ to $\left.8^{\circ} \mathrm{C}\right)$ and $T_{\text {feet }}=23$ to $26^{\circ} \mathrm{C}_{i} 1.5 \mathrm{~min}$ later, $T_{\text {trunk }}$ had not changed, whereas some parts of the feet had reached $28.7^{\circ} \mathrm{C}$.

When a dry otter left the sleeping box after a period of rest, it had 'warm feet', and even if $T_{\text {feet }}$ in some cases had decreased, which depended on $T_{\text {air }}$ and activity, $T_{\text {feet }}$ usually remained above the values of $T_{\text {trunk }}$ and $T_{\text {air, }}$ until the otter went into the water, at least at $T_{\text {air }}>10^{\circ} \mathrm{C}$. Only few data are available for colder $T_{\text {air }}$. During a session in December at $T_{\text {air }}=$ $2.8^{\circ} \mathrm{C}$, the temperature of Naima's feet decreased after leaving the sleeping box. After $14 \mathrm{~min}$ of activity on land, $T_{\text {feet }}$ was still above $T_{\text {air }}$ but the tips of the fingers were $<2{ }^{\circ} \mathrm{C}$ above $T_{\text {air }}$. During 2 other sessions in January at $T_{\text {air }}=4.2$ and $7.1^{\circ} \mathrm{C}$, mean $T_{\text {feet }}$ was still above $T_{\text {air }}$ after, respectively, 10 and 7 min of activity on land, but the tips of the fingers were equal to $T_{\text {air }}$. However, it has to be noted that during the winter sessions the floor of the enclosure was mostly wet.

Most of the time, the legs showed the same surface temperature as the trunk. Heat loss from the legs increased when the otter stretched them, particularly when the fur was wet. Especially the inner part of the legs, which was often not visible on the thermograms, appeared to be warmer than the trunk, both under 'warm feet' and 'cold feet' conditions. For example, in Fig. 1A, the inner part of the left leg was at $20.3 \pm$ $0.4^{\circ} \mathrm{C}$, which was $5.8^{\circ} \mathrm{C}$ higher than the trunk but $8.5^{\circ} \mathrm{C}$ lower than the feet.

\section{Trunk}

The trunk was not an important avenue for heat loss because its surface temperature was mostly near water and/or air temperatures (see Fig. 2). When an otter left the water, $T_{\text {trunk }}$ was at $T_{\text {water }}$ or slightly higher, but usually below $T_{\text {air }}$ (when $T_{\text {water }}<T_{\text {air }}$ ). Then, $T_{\text {trunk }}$ in- 

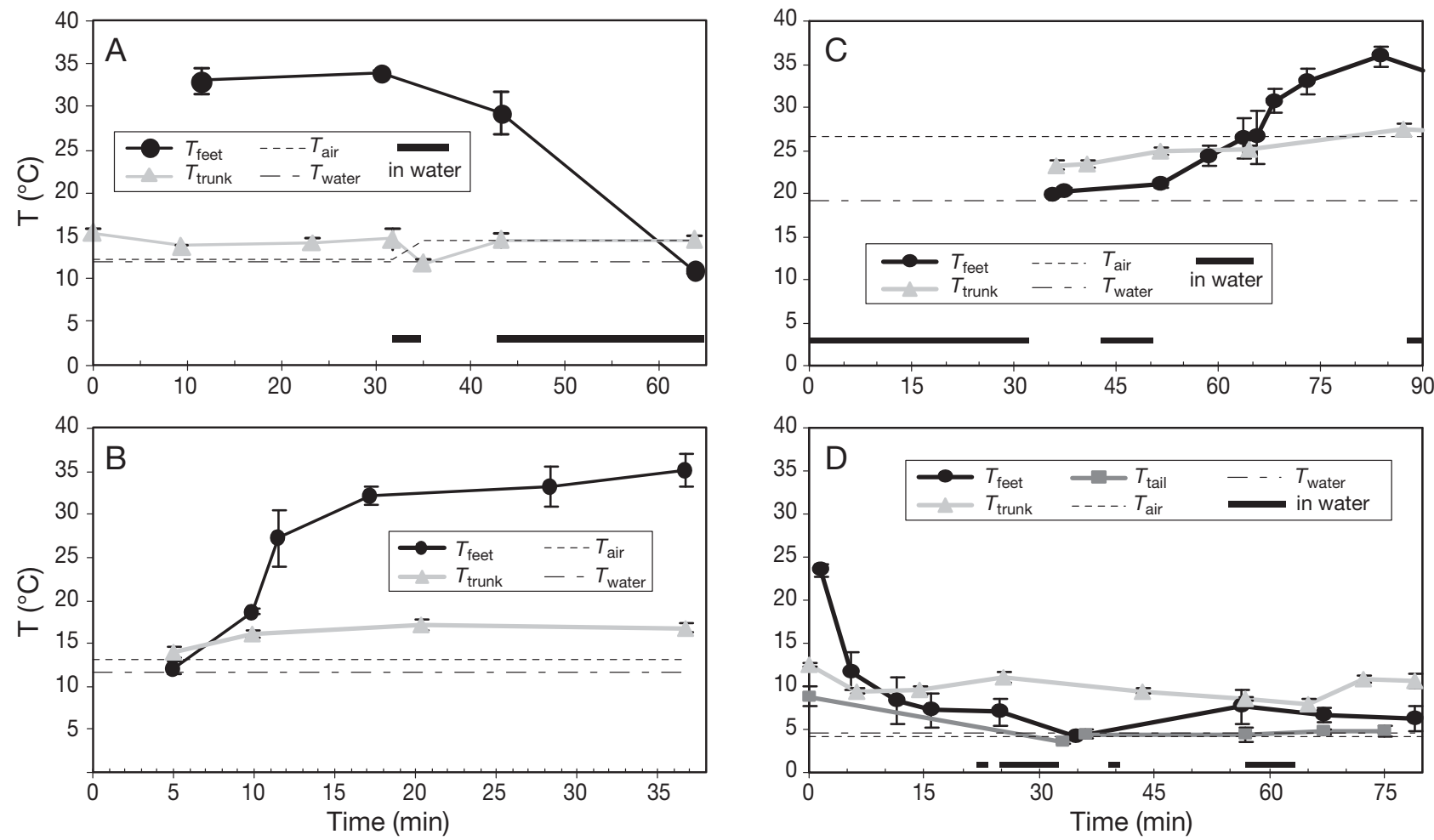

Fig. 2. Lutra lutra. Evaluation of $T_{\text {feet }}$ and $T_{\text {trunk }}$ ( $T_{\text {tail }}$ is also included in 1 graph) during different situations and at different $T_{\text {air }}$ and $T_{\text {water }}$ (A,B: spring; C: summer; D: winter). Error bars: standard deviations. (A) At 0 min, Naima came out of the sleeping box and was dry. The otter spent $33 \mathrm{~min}$ in the indoor room, and then went into the water. The change in $T_{\text {air }}$ was because the temperature outdoors differed slightly from the temperature indoors. (B) At 0 min, Naima had just come out of the water, and then went indoors at 5 min. (C) At 0 min, Naima had just entered the water. (D) At 0 min Naima came out of the sleeping box and was dry. The decrease of $T_{\text {taill, }}$ which could be well documented during this session, is also represented on the graph. This decrease occurred only in the distal one-third of the tail

creased to and eventually above $T_{\text {air, }}$ because the wet guard hairs began to clump together, which 'opened' the fur. However, at $T_{\text {air }}>10^{\circ} \mathrm{C}$, mean $T_{\text {trunk }}$ usually did not become $>5^{\circ} \mathrm{C}$ warmer than $T_{\text {air }}$. At $T_{\text {air }}<10^{\circ} \mathrm{C}$, the difference could reach $8^{\circ} \mathrm{C}$.

We obtained only few recordings of a dry otter, because keeping an active otter dry for $>30$ min could be done only by locking it in a room without a pool. At $T_{\text {air }}>10^{\circ} \mathrm{C}, T_{\text {trunk }}$ tended to stay quite constant during a period of activity and was equal to $T_{\text {air }}$ or up to $5^{\circ} \mathrm{C}$ above $T_{\text {air }}$. Note that at high $T_{\text {air }}$ a mean $T_{\text {trunk }}$ value $>5^{\circ} \mathrm{C}$ warmer than $T_{\text {air }}$ could be due to heating of the fur by radiation from the sun, which could not be completely avoided outdoors, even when the sky was cloudy and the enclosure shadowy. Only few thermograms of a dry otter active on land could be made at $T_{\text {air }}<10^{\circ} \mathrm{C}$, and most of them were taken when the otter had just come out of the sleeping box. During a December session, the trunk temperature of Naima was between 10 and $12^{\circ} \mathrm{C}$ immediately after having left the sleeping box, and about 7 to $9^{\circ} \mathrm{C} 10$ min later $\left(T_{\text {air }}=2.8^{\circ} \mathrm{C}\right)$. The trunk temperature of Teufel was about 9 to $10^{\circ} \mathrm{C}$ at $T_{\text {air }}=6.4^{\circ} \mathrm{C}$.
On several occasions, it was possible to measure the temperature inside of the hair coat, for example when the otter had scratched itself, and thus induced deeper openings of the coat, or when close-ups of the clumps of wet hairs could be made. Thermocouples would be necessary to measure the exact temperature of the otter skin, but IRT allowed us to conclude that the air layer within the otter fur had a temperature $>25^{\circ} \mathrm{C}$, even after a swimming bout (Fig. 3). Temperatures between 25 and $30^{\circ} \mathrm{C}$ at areas just scratched or in gaps between the hairs were measured on many thermograms, including a few of those taken in winter. On one thermogram taken a few seconds after a 9 min long swimming bout $\left(T_{\text {water }}=13.9^{\circ} \mathrm{C}\right)$, temperatures up to $28^{\circ} \mathrm{C}$ were measured on the back, between tufts of wet hair.

Ears, peripalpebral region and vibrissal pads

The ears, the peripalpebral region and the vibrissal pads appeared warm (above $T_{\text {air }}$ ) on every thermogram, even at low $T_{\text {air }}$ and after a swimming bout (Fig. 4). The 

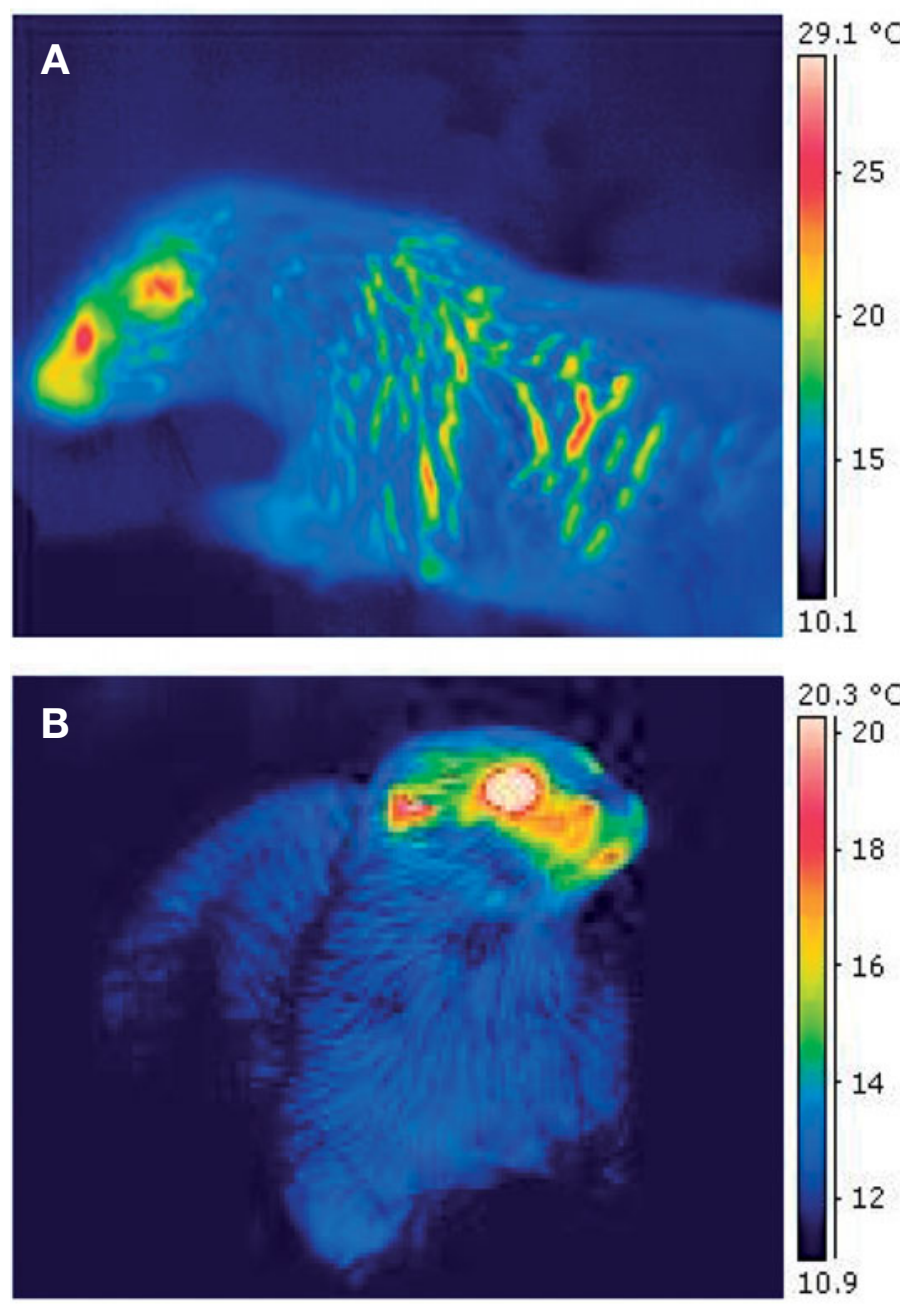

Fig. 3. (A) Lutra lutra. Thermogram of Naima taken 7 min after exiting the water $\left(T_{\text {air }}=13.6^{\circ} \mathrm{C}, T_{\text {water }}=12.9^{\circ} \mathrm{C}\right)$. The temperature at the surface of the fur ranged from 12.5 to $14.5^{\circ} \mathrm{C}$ (blue area), whereas in gaps between tufts of wet hairs, the temperature reached $25.2^{\circ} \mathrm{C}$ (red areas). (B) Thermogram of Robert taken just after exiting the water $\left(T_{\text {air }}=13.3^{\circ} \mathrm{C}, T_{\text {water }}=11.3^{\circ} \mathrm{C}\right)$. The mean temperature at the surface of the trunk was $12.1 \pm 0.2^{\circ} \mathrm{C}$, whereas the mean temperature of the peripalpebral region and mystical vibrissal pads was $17 \pm$ $0.7^{\circ} \mathrm{C}$. The temperature of the ears ranged from 15.5 to $19^{\circ} \mathrm{C}$

ears tended to be the warmest regions, the temperature of which reached $37^{\circ} \mathrm{C}$ (highest value measured), and they were clearly visible on thermograms when the otter swam at the water surface. The temperature of the mystical vibrissal pads reached $34^{\circ} \mathrm{C}$. They tended to be slightly warmer than the peripalpebral region, including the base of the supraciliary and upper genal vibrissae, except for the rim of the eyes, which was as warm as the mystical pads. The temperature at the base of the lower genal vibrissae was measured on only a few thermograms, but was also above $T_{\text {air }}\left(T_{\max }\right.$ measured $\left.=34^{\circ} \mathrm{C}\right)$. During the coldest session $\left(T_{\text {air }}=2.8^{\circ} \mathrm{C}\right)$, temperatures between 15 and $18^{\circ} \mathrm{C}$ were
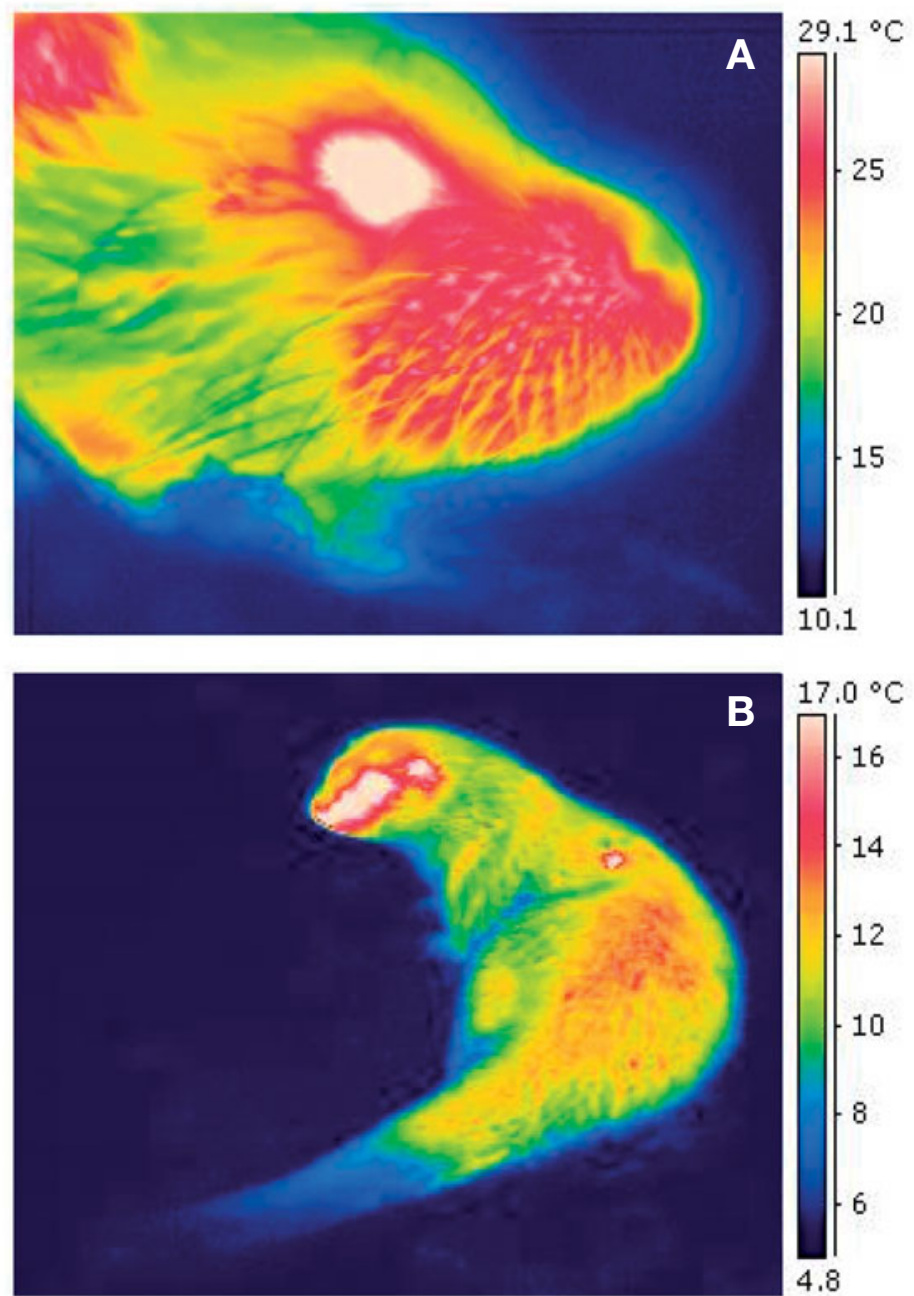

Fig. 4. (A) Lutra lutra. Thermogram of Naima taken 23 min after exiting the water $\left(T_{\text {air }}=13.6^{\circ} \mathrm{C}, T_{\text {water }}=12.9^{\circ} \mathrm{C}\right)$. The mean temperature of the mystical vibrissal pads was $25.2 \pm$ $0.7^{\circ} \mathrm{C}\left(28.2^{\circ} \mathrm{C}\right.$ at the base of each vibrissae $)$, and $18.5 \pm 0.6^{\circ} \mathrm{C}$ at the surrounding regions of the head. The mean temperature measured at the upper genal vibrissal pads was $24.3 \pm$ $0.4^{\circ} \mathrm{C}$. (B) Thermogram of Naima taken 2 min after exiting the water $\left(T_{\text {air }}=7.3^{\circ} \mathrm{C}, T_{\text {water }}=5.7^{\circ} \mathrm{C}\right) . T_{\text {back-proximal tail }}($ yellow $)=$ $11.6 \pm 0.8^{\circ} \mathrm{C}, T_{\text {distal tail }}$ (blue) $=6.4 \pm 1.2^{\circ} \mathrm{C}$

measured at the peripalpebral region and mystical vibrissal pads, and up to $21^{\circ} \mathrm{C}$ at the ears, after a swimming bout $\left(T_{\text {water }}=5.2^{\circ} \mathrm{C}\right.$ ). When the otter was dry, the mystical pads were between 20 and $25^{\circ} \mathrm{C}$ in all winter sessions, and $T_{\text {ears }}$ up to $31^{\circ} \mathrm{C}$ were measured.

\section{Tail}

The tail of wet otters was considerably colder than the trunk at low $T_{\text {air }}\left(<10^{\circ} \mathrm{C}\right)$. When otters were dry, a continuous isothermal area was recognizable from the trunk to the tail, at least with $T_{\text {air }}>10^{\circ} \mathrm{C}$. This was also 

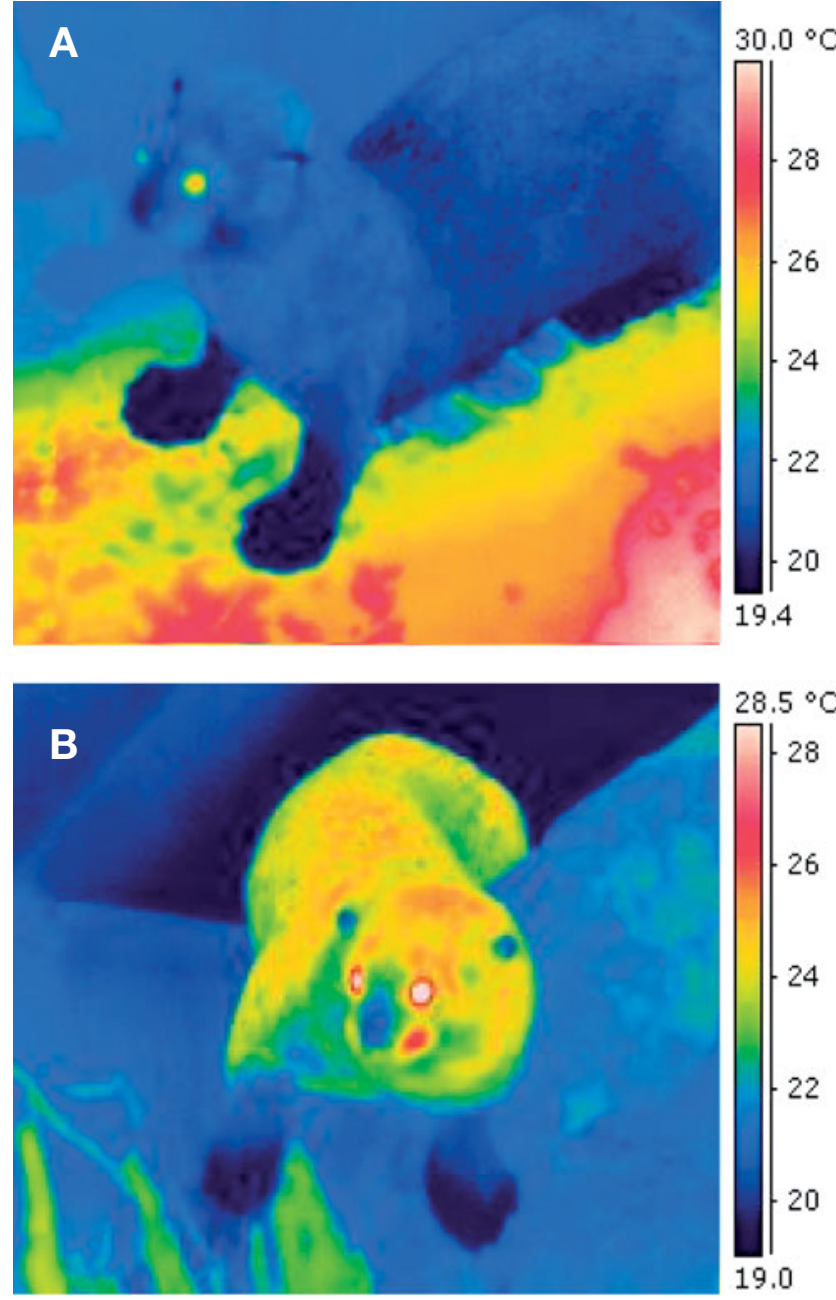

Fig. 5. Pteronura brasiliensis. (A) Thermogram of a giant otter that had just come out of the water $\left(T_{\text {air }}=22.4^{\circ} \mathrm{C}, T_{\text {water }}=\right.$ $\left.19.1^{\circ} \mathrm{C}\right) ; T_{\text {trunk }}=20.8 \pm 0.2^{\circ} \mathrm{C}, T_{\text {feet }}=19.7 \pm 0.2^{\circ} \mathrm{C}$. (B) Thermogram taken $30 \mathrm{~s}$ after the giant otter came out of water $\left(T_{\text {air }}=\right.$ $\left.22.4^{\circ} \mathrm{C}, T_{\text {water }}=19.1^{\circ} \mathrm{C}\right) ; T_{\text {trunk }}=24.5 \pm 0.3^{\circ} \mathrm{C}, T_{\text {feet }}=19.7 \pm$ $0.2^{\circ} \mathrm{C}, T_{\text {ears }}=20.7 \pm 0.3^{\circ} \mathrm{C}, T_{\text {mystical pads }}=26.4 \pm 0.2^{\circ} \mathrm{C}$ and $T_{\text {peripalpebral }}=24.2 \pm 0.9^{\circ} \mathrm{C}$

the case in wet otters during the spring and summer sessions, except on 3 occasions in May. On a thermogram taken $10 \mathrm{~min}$ after Naima had left the water $\left(T_{\text {air }}=13.6^{\circ} \mathrm{C}, T_{\text {water }}=12.9^{\circ} \mathrm{C}\right)$, the tail was about $2^{\circ} \mathrm{C}$ below $T_{\text {air, }}$ whereas the back was $1^{\circ} \mathrm{C}$ above $T_{\text {air }}$. On another thermogram of Robert, taken shortly after a swimming bout $\left(T_{\text {air }}=14.7^{\circ} \mathrm{C}, T_{\text {water }}=11.2^{\circ} \mathrm{C}\right), T_{\text {tail }}$ was similar to $T_{\text {air, whereas }} T_{\text {trunk }}$ was about $3^{\circ} \mathrm{C}$ above $T_{\text {air }}$. A $T_{\text {tail }}$ value lower than $T_{\text {trunk }}$ was never recorded at $T_{\text {air }}$ $>15^{\circ} \mathrm{C}$. On 2 thermograms taken at, respectively, $T_{\text {air }}=$ $19.9^{\circ} \mathrm{C}$ and $T_{\text {air }}=29.4^{\circ} \mathrm{C}$, small openings of the wet fur of the tail were at 28 to $31^{\circ} \mathrm{C}$, about $4^{\circ} \mathrm{C}$ higher than the surface of the fur, which indicated that a warm insulating air layer was present under the surface of the fur, even at the tail.
The tail appeared colder than the trunk on every thermogram representing a wet otter taken during the winter sessions ( $T_{\text {air }}$ between 2.8 and $8.1^{\circ} \mathrm{C}$ ), except in a few particular cases (very high activity or only short swimming bout after a time in the sleeping box). Differences up to $7^{\circ} \mathrm{C}$ between $T_{\text {trunk }}$ and $T_{\text {tail }}$ were recorded. Only the distal part of the tail (about onethird to two-thirds of the tail length) was colder, whereas the proximal part was at the same temperature as the back (Fig. 4B). Within the 'cold part', the temperature decreased toward the tip. Apparently, the temperature of the tail decreased to $T_{\text {water }}$ during a swimming bout, and, when the otter came out of the water, $T_{\text {tail }}$ remained constant at a temperature similar to that of the water. An increase of $T_{\text {tail }}$ after a swimming bout was not recorded until the otter went back into the sleeping box.

\section{Pteronura brasiliensis}

Thermographic pictures of the 2 giant otters studied were recorded during 3 sessions. Since it was not possible to distinguish between the individuals, the results for both otters were combined. During the first 2 sessions, the otters were in an indoor enclosure with a pool $\left(T_{\text {air }}=22.4^{\circ} \mathrm{C}, T_{\text {water }}=19.1^{\circ} \mathrm{C}\right)$. The otters went into the pool every few minutes or even seconds, and never stayed $>5 \mathrm{~min}$ on land (usually $<3 \mathrm{~min}$ ). Despite this, $T_{\text {trunk }}$ values around 24 to $25^{\circ} \mathrm{C}$ were recorded on the majority of the thermograms. When the otters had just come out of the water, $T_{\text {trunk }}$ was about 20 or $21^{\circ} \mathrm{C}$, and then increased to temperatures of 24 to $25^{\circ} \mathrm{C}$ in $<1 \mathrm{~min}$ (Fig. 5).

$T_{\text {feet }}$ was always slightly beneath $T_{\text {trunk }}$ at the end of a swimming bout $\left(T_{\text {feet }}=19.5 \pm 0.2^{\circ} \mathrm{C}, T_{\text {trunk }}=20.5 \pm\right.$ $0.5^{\circ} \mathrm{C}$, values measured on 4 thermograms taken within $30 \mathrm{~s}$ after exiting the water, $\mathrm{n}=5$ measuring points thermogram ${ }^{-1}$ ). Then, while $T_{\text {trunk }}$ increased very rapidly, $T_{\text {feet }}$ remained constant during the following minutes. The same was observed with the temperature of the tail (Fig. 6). The mean temperatures measured at the surface of the feet and the tail during the 5 min following the swimming bout were $T_{\text {feet }}=$ $20 \pm 0.6^{\circ} \mathrm{C}$ and $T_{\text {tail }}=20 \pm 0.5^{\circ} \mathrm{C}$ (mean values calculated using 5 randomly chosen thermograms).

Feet and tail were always the coldest parts of the body. An increase of $T_{\text {feet }}$ and $T_{\text {tail }}$ above $T_{\text {trunk }}$ was observed only during the third session, when the otters were kept in a part of their enclosure without water for $1 \mathrm{~h}$ (Fig. 7). The otters had just come out of water at the beginning of the session. As usual, $T_{\text {trunk }}$ increased very rapidly and was above $T_{\text {air }}\left(24.5^{\circ} \mathrm{C}\right)$ at the end of the first minute after exiting the water. Afterwards, $T_{\text {trunk }}$ increased slowly during the first $30 \mathrm{~min}$ and then 


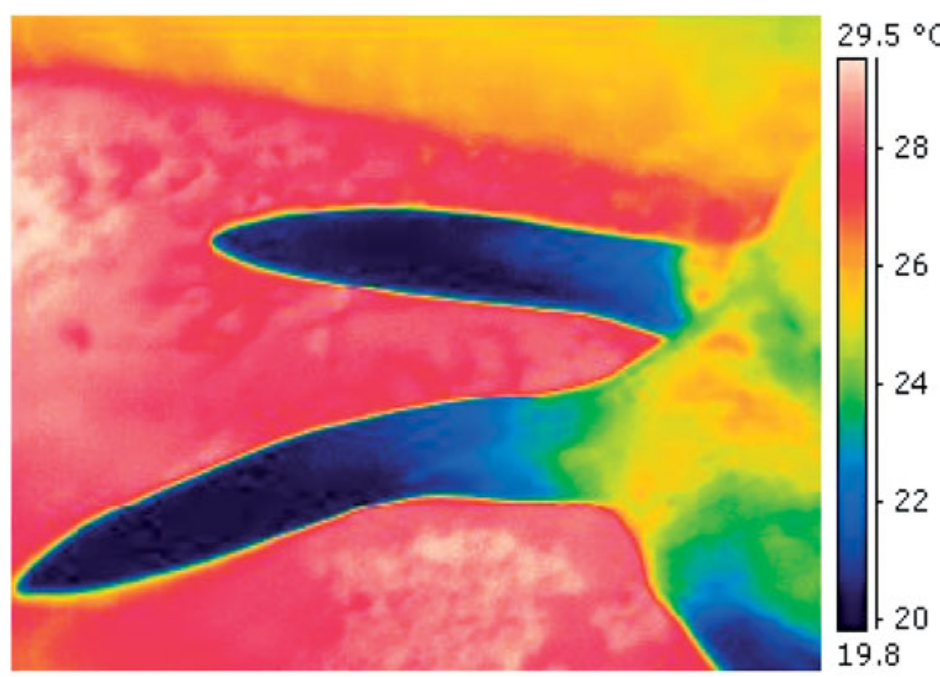

Fig. 6. Pteronura brasiliensis. Thermogram representing the tails of 2 giant otters, taken $<5$ min after a swimming bout. Upper otter: $T_{\text {tail }}=$ $20.3 \pm 0.4^{\circ} \mathrm{C}$; lower otter: $T_{\text {tail }}=20.3 \pm 0.3^{\circ} \mathrm{C}, T_{\text {back }}=24.9 \pm 0.6^{\circ} \mathrm{C} . T_{\text {tail }}$ was measured for the distal two-thirds of the tail (dark blue area). The transitory part (light blue area) had a mean $T$ of $22.6 \pm 0.2^{\circ} \mathrm{C}$

remained constant during the last $30 \mathrm{~min} . T_{\text {feet }}$ and $T_{\text {tail }}$ increased slowly and continuously during the first $30 \mathrm{~min}$, until they reached $T_{\text {air }}$. After $40 \mathrm{~min}, T_{\text {feet }}$ and $T_{\text {tail }}$ increased more rapidly, and, after $50 \mathrm{~min}, T_{\text {feet }}$ and $T_{\text {tail }}$ were between 1 and $3^{\circ} \mathrm{C}$ above $T_{\text {trunk }}$. Actually heat loss from the feet and tail began only when heat loss from the trunk stagnanted.

The temperature of the ears was slightly above $T_{\text {water }}$ when the otters came out of water and then increased up to $T_{\text {air }}$ after a few minutes. Temperatures $>25^{\circ} \mathrm{C}$ were measured on the mystical vibrissal pads within the minute after exiting the water (see also Fig. 3B); the peripalpebral region was also above $T_{\text {air }}$.

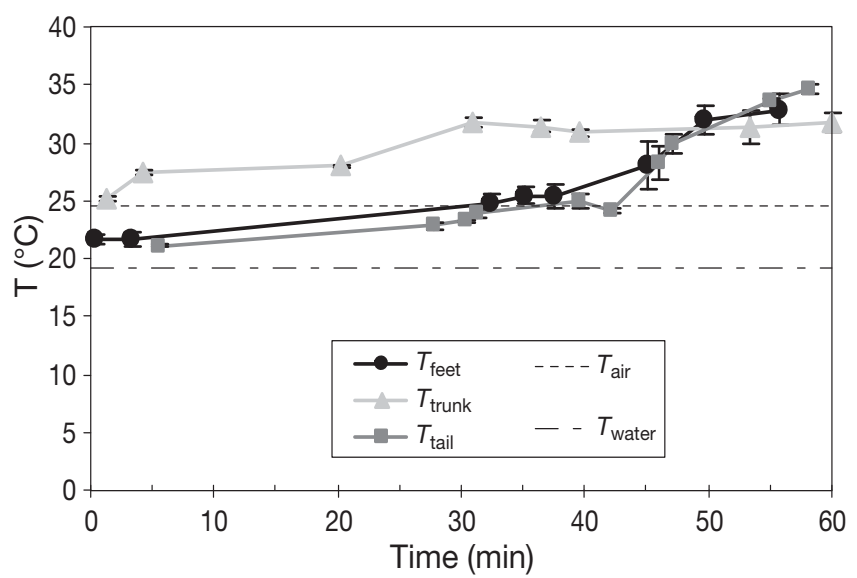

Fig. 7. Pteronura brasiliensis. Graph representing the development of $T_{\text {trunk, }}, T_{\text {feet }}$ and $T_{\text {tail }}$ in 2 giant otters, during the hour following a swimming bout. The otters had no access to water and were dry at the end of the session

\section{DISCUSSION}

\section{Surface temperature and thermal windows: heat loss from feet and tail}

In otters, vasomotion in feet and tail is the principal heat loss regulation mechanism. In the particularly well-furred Eurasian otter Lutra lutra, the sparsely furred feet are the only part of the body where considerable heat loss can occur. When the otter is in water and/or at low $T_{\text {air, }}$ vasoconstriction in the skin of the feet prevents excessive heat loss. Vasodilatation occurs in the feet when excess heat has to be dissipated. This effective thermoregulatory surface is relatively small, but $T_{\text {feet }}$ can be considerably above $T_{\text {air, }}$ and this happens very rapidly when the otter is in a heat load situation. Otters also have large paws, compared to other animals of similar size, and the interdigital webbings increase the surface area available for heat loss.

Unlike the feet, the tail of the Eurasian otter is well insulated. However, its insulating layer must be very thin, and is apparently insufficient at lower temperatures, particularly in water $<10^{\circ} \mathrm{C}$. Thus, vasoconstriction occurs in order to prevent heat loss and the skin cools to $T_{\text {water. }}$ In the giant otter Pteranura brasiliensis, the tail is covered with very short fur, and thus is poorly insulated. In these species, both feet and tail are used as thermal windows. The use of the feet and tail as thermoregulatory areas has also been demonstrated in the small-clawed otter Amblonyx cinereus (Kuhn 2009).

Sokolov (1962) considered the tail to be a site for dissipating excess heat in the majority of semi-aquatic forms. The regulation of heat loss through the feet and tail has been demonstrated, for example, in the American and European beaver Castor canadensis and $C$. fiber, respectively, the muskrat Ondatra zibethicus, the coypu Myocastor coypus and the Australian water rat Hydromys chrysogaster (Johansen 1962, Steen \& Steen 1965, Fish 1979, Fanning \& Dawson 1980, MacArthur 1984, Krattenmacher \& Rübsamen 1987, MacArthur \& Dick 1990). The plantar surfaces of minks Mustela vison resting in air at $23.8^{\circ} \mathrm{C}$ had a temperature of about $37^{\circ} \mathrm{C}$ (Williams 1986). When submerged in water at $24.6^{\circ} \mathrm{C}$, their temperature was about 2 to $3^{\circ} \mathrm{C}$ above $T_{\text {water. }}$ A heavily sedated mink resting in water did not exhibit peripheral vasoconstriction, and the skin temperature of the feet remained close to the body temperature. Thus, the body temperature of this individual decreased at a rate twice as high as that in minks demonstrating peripheral vasoconstriction. In small terrestrial mammals, the feet, ears and tails are not the areas of heat loss, but the orbital region and its surroundings is (Meyer 2004). 
The ability to dissipate or retain heat depends on the anatomy of the peripheral circulatory system. An elaborate countercurrent arrangement of veins and arteries and arteriovenous anastomoses (AVAs) is found in the hind feet and tail of beavers (Cutright \& McKean 1979), but little is known about the peripheral circulatory system of otters. Information is available only for Lontra canadensis and Enhydra lutris, but we expect the circulatory systems of Lutra lutra and Lontra canadensis to be similar because of the anatomical and ecological similarities between both species. The skin is relatively thin at the feet, particularly in the interdigital webbings, which are also highly vascularised (Tarasoff 1972, 1974, Baitchman \& Kollias 2000), whereby Tarasoff considers the vascularisation of the hind feet of $L$. canadensis to be similar to that of a terrestrial carnivore. He observed that the hind feet in E. lutris are more vascularised than in L. canadensis, but less than in pinnipeds, but did not find retia mirabilia comparable to those in pinnipeds. Nevertheless, our study showed that blood flow in the feet of Lutra lutra changed very rapidly in response to changing thermal conditions, not only in the interdigital webbings, and that heat loss decreased to minimal values during a swimming bout, even in water $<5^{\circ} \mathrm{C}$. A rapid local response to cold is also found in rat tail skin as mediated by a sympathetical supraspinal control of the tail vasculature (Kalincik et al. 2009). However, no such information is available for otters or semi-aquatic mammals. Fanning \& Dawson (1980) observed that in submerged Australian water rats, the feet were at temperatures close to or equal to $T_{\text {water, }}$ despite the absence of particular countercurrent heat exchangers, and concluded that the low skin temperatures must have principally been achieved by simple vasoconstriction. However, this species is not adapted to long swimming bouts in nearly freezing water and to low air temperatures as is the Eurasian otter. We could not find any information on the circulatory system of the giant otter. So far, further examination of the circulatory system of otters, particularly in the appendages of the body, is needed.

\section{Insulating capacity and importance of fur integrity}

While the giant otter can lose a considerable amount of heat from the whole body, in the Eurasian otter $T_{\text {trunk }}$ tends to follow $T_{\text {air, }}$ which is generally observed in well-furred mammals (Hammel 1955). Infrared thermography visualises 'heat', and thus gives us a good 'representation' of the insulating capacity of the otter hair coat. The existence of '2 layers' around the body of otters was observed on many thermograms of the Eurasian otter. The warm inner layer is formed by the air trapped within the extremely dense wool (sec- ondary) hair coat of the fur, and warmed by the heat produced by the body, which is thus conserved for the most part instead of being lost to the surrounding air. This heated, insulating air layer is maintained in the water. The external layer is made of the upper part (shield) of the guard (primary) hairs, which are longer than the wool (secondary) hairs. In water, the large and flat shields lie parallel to the body, and form a kind of wet film which protects the underlying layer from becoming cold and wet. This layer of primary hair shields confers to the otters a slippery aspect when they leave the water. Although the guard hairs show gas-filled chambers in their medulla, the density of this type of hair per $\mathrm{cm}^{2}$ compared to the wool hairs is $<1 \%$ (Kuhn 2009), i.e. clearly too low to have any influence on heat conservation within the hair coat. The guard hairs are more important to 'thicken' the wool hair coat by piloerection so that the insulating properties can be improved in their reaction to rapid drops in temperature. Piloerection is induced by the contraction of the arrector pili muscles, following activation of the $\alpha 1$ adrenoceptor (Stephens 1986, Ennis \& Coss 2006).

On many thermograms we measured a thermal gradient of $>10^{\circ} \mathrm{C}$ between the surface of the fur and the inner layer. A temperature of $28^{\circ} \mathrm{C}$ was measured within the inner hair coat layer of an otter who had just come out of water at $13.9^{\circ} \mathrm{C}$; temperatures $>25^{\circ} \mathrm{C}$ were also measured in winter. These measurements gave us the temperatures at different points situated within the inner layer, which might be somewhat beneath the temperature of the skin. Kruuk \& Balharry (1990) measured the temperature in the air layer immediately adjacent to the skin, when cold water at $6^{\circ} \mathrm{C}$ was run along the outside of fur sections that were stretched over a copper vessel maintained at $35^{\circ} \mathrm{C}$. The mean temperature inside the fur near the skin, measured using thermocouples, was $29.1 \pm 1.1^{\circ} \mathrm{C}$.

Several mammals living in cold climates (arctic or mountains) have a fur the thermal conductivity of which, in air, is lower than that of otter fur; however, in water, the otter hair coat shows the best insulating capacity, at least for Lutra lutra, Lontra canadensis and Enhydra lutris (Scholander et al. 1950, Morrison et al. 1974). This insulating system seems to be fragile, i.e. on the thermograms we observed that each disturbance in the external protective shield induced an increase of several degrees in the surface temperature of the disturbed area, which means a considerable increase in heat loss.

\section{Surface temperature of sensory organs}

In the Eurasian otter, surface temperatures of the ears, peripalpebral region and vibrissal pads were 
never $<15^{\circ} \mathrm{C}$, even after a swimming bout and in winter; such temperatures at the surface of the fur indicate substantially higher temperatures of the skin. This heating may be due to increased blood flow through the dense capillary network surrounding, for example, the large sensory hair follicles. This occurs in order to ensure a continuous good functioning of the sensory organs, because cooling would impair sensitivity (Gescheider et al. 1997). Dehnhardt et al. (1998) showed with IRT that, in seals, which also have to deal with the large cooling power of water, the appropriate operating temperature of the vibrissal pads is maintained, even in water at $1.2^{\circ} \mathrm{C}$.

In the giant otter, the mystical vibrissal pads were also warmer than the surrounding regions of the head, after a swimming bout. Eurasian otters and giant otters are principally fish eaters and catch their prey with their mouths. Radinsky (1968) demonstrated an expansion of the coronal gyrus for the brain of these species, indicating a somatic sensory specialisation of the head region, presumably in the form of extremely sensitive vibrissae. A specific heating of the vibrissal pads was not observed in small-clawed otters (Kuhn 2009), the less aquatic otters, which feed principally on invertebrates caught with the fore paws and show an enlarged primary somatic sensory projection area related to the forelimbs.

\section{Adaptive value of body surface temperature variations}

Few studies have compared the surface temperature regulation between species belonging to the same taxonomic group, but occurring in different climatic regions. An IRT study of the surface temperature of 3 species of foxes showed that the species living in the coldest regions had the smallest thermoregulatory surface areas, whereas the species living in the hottest and most arid climates had the largest ones (Klir \& Heath 1992).

This is similar in otters. The giant otter can dissipate the greatest amount of heat, because it has the largest appendages with the least hair (also the largest relative to the body). It uses both the feet and tail as thermal windows, but can also dissipate a considerable amount of heat through the whole body. This is due to a coat of short hair, which allows greater heat transfer than in the Eurasian otter; the giant otter has hairs that are half as long as those of the Eurasian otter, and is one of the 2 otter species with the shortest and thinnest hairs (Kuhn 2009). Giant otter use their feet to dissipate excessive heat quite late, compared to Eurasian otter, which indicates superior heat tolerance in the former species. The giant otter is a diurnal tropical species living in the Amazon Basin, and the ability to lose a considerable amount of heat on land is advantageous. However, this species is also subjected to aquatic cooling, and thus vasoconstriction in the feet and tail reduces heat loss in water. Moreover, the fur is short, but dense, and may provide sufficient insulation in water $>20^{\circ} \mathrm{C}$. In the well-furred Eurasian otter, the feet were the only region in which considerable temperature fluctuations and heat dissipation occurred. So the surface available for heat loss is relatively small, and this could be a limiting factor in air.

As far as we know, the thermoneutral zone of the Eurasian otter has not been clearly determined, and the thermoregulation of the giant otter has not yet been studied. During our study, we did not encounter subfreezing temperatures or temperatures $>30^{\circ} \mathrm{C}$. So, further studies would be necessary to complete our information on surface temperature regulation in the Lutrinae, including exposing the animals (with care) to a wider range of air and water temperatures than those used in our study and recording more otters that were kept dry. The data on tropical species, in particular, need to be supplemented.

Acknowledgements. Special recognition is given to the German Otter-Centre (Otter-Zentrum) and Association for Otter Conservation (Aktion Fischotterschutz) for supporting this project and to the Hagenbeck Zoo (Hamburg, Germany), where we were able to record thermographs of giant otters. We gratefully acknowledge the help of Prof. Dr. Jörg Ganzhorn (Institute of Zoology, University of Hamburg) and the financial support of the German Otter Foundation (Deutsche Otter Stiftung). Sincere thanks are also due to Joachim Sarfels and FLIR Systems for making the infrared thermocamera available to us and for technical advice. In memory of the late Claus Reuther, founder of the Otter-Zentrum and Aktion Fischotterschutz.

\section{LITERATURE CITED}

Baitchman EJ, Kollias GV (2000) Clinical anatomy of the North American river otter (Lontra canadensis). J Zoo Wildl Med 31:473-483

Clark JA (1976) Effects of surface emissivity and viewing angle on errors in thermography. Acta Thermogr 1:138-141

Costa DP, Kooyman GL (1984) Contribution of specific dynamic action to heat balance and thermoregulation in the sea otter Enhydra lutris. Physiol Zool 57:199-203

Cutright WJ, McKean T (1979) Countercurrent blood vessel arrangement in beaver (Castor canadensis). J Morphol 161: 169-176

Cuyler C, Wiuslrod R, Øristland NA (1992) Thermal infrared radiation from free living whales. Mar Mamm Sci 8: $120-134$

> Dehnhardt G, Mauck B, Hyvärinen H (1998) Ambient temperature does not affect the tactile sensitivity of mystical vibrissae in harbour seals. J Exp Biol 201:3023-3029

> Ennis M, Coss RG (2006) Orbital frontal cortex ablations of rock squirrels (Spermiophilus variegatus) disinhibit innate antisnake behavior. Behav Neurosci 120:1299-1307

Fanning FD, Dawson TJ (1980) Body temperature variability 
in the Australian water rat, Hydromys chrysogaster, in air and in water. Aust J Zool 28:229-238

Fish FE (1979) Thermoregulation in the muskrat (Ondatra zibethicus): the use of regional heterothermia. Comp Biochem Physiol A 64:391-397

Fish FE, Smelstoys J, Baudinette RV, Reynolds PS (2002) Fur does not fly, it floats: buoyancy of pelage in semi-aquatic mammals. Aquat Mamm 28:103-112

Gescheider GA, Thorpe JM, Goodarz J, Bolanowski SJ (1997) The effects of skin temperature on the detection and discrimination of tactile stimulation. Somatosens Mot Res 14:181-188

Hammel HT (1955) Thermal properties of fur. Am J Physiol 182:369-376

Iversen JA, Krog J (1973) Heat production and body surface area in seals and sea otter. Norw J Zool 21:51-54

Johansen K (1962) Heat exchange through the muskrat tail. Evidence for vasodilator nerves to the skin. Acta Physiol Scand 55:160-169

Kalincik T, Jozefcikova K, Waite PME, Carrive P (2009) Local response to cold in rat tail after spinal cord transection. J Appl Physiol 106:1976-1985

Kenyon KW (1969) The sea otter in the eastern Pacific Ocean. North Am Fauna 68:1-352

Klir JJ, Heath JE (1992) An infrared thermographic study of surface temperature in relation to external thermal stress in three species of foxes: the red fox (Vulpes vulpes), Arctic fox (Alopex lagopus), and kwit fox (Vulpes macrotis). Physiol Zool 65:1011-1021

Krattenmacher R, Rübsamen K (1987) Thermoregulatory significance of non-evaporative heat loss from the tail of the coypu (Myocastor coypus) and the tammar-wallaby (Macropus eugenii). J Therm Biol 12:15-18

Kruuk H, Balharry D (1990) Effects of sea water on thermal insulation of the otter, Lutra lutra. J Zool (Lond) 220: 405-415

Kruuk H, Balharry E, Taylor PT (1994) Oxygen consumption of the Eurasian otter Lutra lutra in relation to water temperature. Physiol Zool 67:1174-1185

Kruuk H, Taylor PT, Mom GAT (1997) Body temperature and foraging behavior of the Eurasian otter (Lutra lutra), in relation to water temperature. J Zool (Lond) 241:689-697

Kuhn R (2009) Comparative analysis of structural and functional hair coat characteristics, including heat loss regulation, in the Lutrinae (Carnivora: Mustelidae). $\mathrm{PhD}$ thesis, University of Hamburg, Hamburg

MacArthur RA (1984) Aquatic thermoregulation in the muskrat (Ondatra zibethicus): energy demands of swimming and diving. Can J Zool 62:241-248

MacArthur RA, Dick AP (1990) Aquatic thermoregulation of captive and free-ranging beavers (Castor canadensis). Can J Zool 68:2409-2416

Mauck B, Bilgmann K, Jones DD, Eysel U, Dehnhardt G (2003) Thermal windows on the trunk of hauled-out seals: Hot spots for thermoregulatory evaporation? J Exp Biol 206:1727-1738

McCafferty DJ, Moncreiff JB, Taylor JR, Boddie GF (1998) The use of IR thermography to measure the radiative temperature and heat loss of a barn owl (Tyto alba). J Therm

Editorial responsibility: Victor Benno Meyer-Rochow, Bremen, Germany
Biol 23:311-318

Meyer W (2004) Zu den Möglichkeiten der thermographischen Erfassung einer regionalen Wärmeabgabe bei Kleinsäugern. Kleintierpraxis 49:233-237

Morrison P, Rosenmann M, Estes J (1974) Metabolism and thermoregulation in the sea otter. Physiol Zool 47:218-229

Øritsland NA (1968) Variations in the body surface temperature of the harp seal. Acta Physiol Scand 73:35A-36A

Øritsland NA, Lentfer JW, Ronald K (1974) Radiative surface temperatures of the polar bear. J Mammal 55:459-461

Pabst DA, Harradine TM, McLellan WA, Barbieri MM, Meagher EM, Scott MD (2002) Infrared thermography as a tool to assess thermal function of the bottlenose dolphin (Tursiops truncatus) dorsal fin. Am Zool 41:1548

Pfeiffer P, Culik BM (1998) Energy metabolism of underwater swimming in river-otters (Lutra lutra L.). J Comp Physiol B 168:143-148

Phillips PK, Sanborn AF (1994) An infrared thermographic study of surface temperature in three ratites: ostrich, emu and double-wattled cassowary. J Therm Biol 19:423-430

Porter W, Gates DG (1969) Thermodynamic equilibria of animals with environment. Ecol Monogr 39:227-244

Radinsky LB (1968) Evolution of somatic sensory specialisation on otter brains. J Comp Neurol 134:495-505

Scholander PF, Walters V, Hock R, Irving L (1950) Body insulation of some arctic and tropical mammals and birds. Biol Bull 99:225-236

Sokolov W (1962) Adaptations of the mammalian skin to the aquatic mode of life. Nature 195:464-466

Speakman JR, Ward S (1998) Infrared thermography: principles and applications. Zoology (Jena) 101:224-232

> Steen I, Steen JB (1965) Thermoregulatory importance of the beaver's tail. Comp Biochem Physiol A 15:267-270

Stephens MDB (1986) Drug-induced piloerection in man: an $\alpha 1$-adrenoceptor agonist effect? Hum Toxicol 5:319-324

Tarasoff FJ (1972) Comparative aspects of the hind limbs of the river otter, sea otter and seals. In: Harrison RJ (ed) Functional anatomy of marine mammals, Vol 1. Academic Press, London, p 333-359

Tarasoff FJ (1974) Anatomical adaptations in the river otter, sea otter and harp seal with reference to thermal regulation. In: Harrison RJ (ed) Functional anatomy of marine mammals, Vol 2. Academic Press, London, p 111-141

Weisel JW, Chandrasekaran N, Peterson RO (2005) River otter hair structure facilitates interlocking to impede penetration of water and allow trapping of air. Can J Zool 83: 649-655

Williams TM (1986) Thermoregulation of the North American mink during rest and activity in the aquatic environment. Physiol Zool 59:293-305

Williams TM (1989) Swimming by sea otters: adaptations for low energetic cost locomotion. J Comp Physiol A 164: 815-824

Williams TD, Allen DD, Groff JM, Glass RL (1992) An analysis of California sea otter (Enhydra lutris) pelage and integument. Mar Mamm Sci 8:1-18

Zahner V, Müller R (2003) Thermoregulation-a main function of the beaver tail? In: Proc 3rd Int Beaver Symp. VZZ, Arnhem (poster)

Submitted: April 27, 2009; Accepted: July 2, 2009

Proofs received from author(s): August 3, 2009 